\title{
PERSPECTIVA INÉDITA SOBRE A DOENÇA COMPORTAMENTAL NO TRABALHO
}

\section{Cecilia W. Bergamini}

Livre-Docente pela Faculdade de Economia, Administração e Contabilidade, Universidade de São Paulo - São Paulo - SP, Brasil e Professora da Escola de Administração de Empresas de São Paulo, Fundação Getulio Vargas - São Paulo - SP, Brasil cecilia@ceciliabergamini.com.br

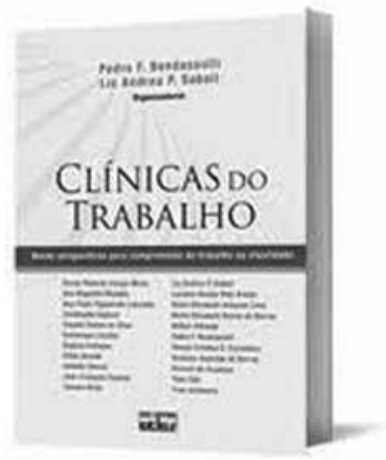

\section{CLÍNICAS DO TRABALHO: novas perspectivas para a compreensão do trabalho na atualidade}

De Pedro F. Bendassolli e Lis Andrea P. Soboll (org.), São Paulo, Editora Atlas, 2011, 288 p.
O livro inaugura para os leitores brasileiros uma nova era de compreensão da interação homem-trabalhoorganização. Não mais dentro de uma perspectiva ingênua como aquela divulgada pelos populares Manuais de Administração que pretenderam simplificar e divulgar normas gerais de como lidar com as pessoas no contexto organizacional. Para tanto, Pedro F, Bendassoli e Lis Andrea P. Soboll, organizadores da obra, reuniram um conjunto de autores de reconhecida competência em psicopatologia do comportamento organizacional. Como os próprios organizadores admitem que "a clínica do trabalho aproxima-se da clínica social, mas também contempla as vivências de sofrimento, neste caso, ancoradas nas experiências objetivas e subjetivas" dos trabalhadores. O livro contempla quatro teorias clínicas do trabalho - Clínica da Atividade, Psicossociologia, Psicodinâmica do Trabalho e Ergologia.

Dividida em três partes, a obra propõe na primeira delas os Fundamentos das Clínicas do Trabalho, na segunda, as Perspectivas Francesas e finaliza com as Perspectivas Brasileiras.

$\mathrm{Na}$ primeira parte é feita uma introdução que delineia aquelas situações que levam à insegurança e formação de conflito que configuram "neuroses de trabalho". A obra não aborda apenas a influência deletéria do trabalho mas considerada que ele pode se caracterizar como atividade criativa e meio de sublimação.

As patologias são subdivididas em três grupos denominadas: da atividade, da solidão e indeterminação no trabalho e, finalmente, aquelas associadas aos maus tratos e violência no trabalho. Para os autores o sofrimento surge das solicitações de cunho social, econômico e cultural. A tônica da maioria dos artigos é propor que se reformulem os pressupostos das políticas organizacionais abandonando um exame superficial e levando em conta os processos de subjetivação do sofrimento, retratando o mundo interno de cada um.

Filiações Teóricas das Clínicas do Trabalho, proposto por Lhuilier, apresenta no segundo artigo dois enfoques distintos que são as correntes teóricas da psicologia social clínica e a psicopatologia do trabalho. A autora sinaliza ser o trabalho, o ponto fundamental para o encontro e troca com os demais, sem esquecer a importância do conflito indivíduoorganização e suas consequências.

$\mathrm{Na}$ segunda parte do livro cabe a Gernet e Desjours apontarem importantes restrições sobre a Avaliação do Trabalho e o Reconhecimento, ressaltando que quando ela não retrata 
a verdade pode remeter o avaliado à "alienação mental, fazendo sentir seus efeitos na construção do sentido do trabalho". A avaliação fidedigna atende à expectativa humana de servir-se do olhar do outro para chegar à confirmação da própria identidade.

Yves Clot apresenta no artigo seguinte a distinção entre a Clínica do Trabalho e Clínica da Atividade considerando que o cotidiano é composto dos conflitos ocultos, o que pode exercer um papel nocivo diminuindo e restringindo as pessoas. Com exceção do artigo oito - Manifesto por um Ergoengajamento - escrito por Yves Schwarts e do Prefácio assinado por Ives Clot todos os artigos oferecem inúmeras sugestões bibliográficas de importantes autores que podem e devem ser consultadas pelos interessados no assunto.

A Nova Gestão Paradoxal (NGP) de Vincent de Gaulejac propõe no quinto artigo o exame de confrontações conflitantes entre os indivíduos que uma vez pegos em erro, correm o risco de serem excluídos. A evasão com muita freqüência é feita usando a doença que permite fugir das exigências paradoxais e injunções que não têm sentido, apesar do sentimento difuso de assédio que paira no ar.

Em Psicodinâmica do Trabalho e Psicossociologia, Gilles Amado e Eugène Enriquez apresentam formas de conflito, entre dominantes e dominados, organizações formais e informais, nações, classes, religiões etc trabalhando dentro daquilo que chamam de "psicossociologia do conflito", que nutre suas diretrizes na orientação psicanalítica. Com reconhecida coerência, os autores exploram como os funcionários não são mais avaliados pela qualidade do trabalho, mas sim pela qualidade de vender a imagem na empresa. Os autores ressaltam como funciona o recalque e a repressão no mundo da produção, não mais do trabalho.

Ainda dentro das perspectivas francesas, Chanlat aborda o Desafio social da gestão. Recomenda aos gestores a importância da melhor compreensão das dimensões centrais do comportamento humano. O autor é bem claro ao propor a dimensão subjetiva da ação, uma vez que as pessoas têm desejos, sonhos e ambições enfatizando a impossibilidade de dissociar a vida psíquica de cada um da experiência social concreta. Além disso, levanta a importância do reconhecimento que está no coração da dinâmica humana no trabalho. Vários são os aspectos altamente relevantes para aprofundar a compreensão do comportamento propondo o autor "que o homem é um animal que fala" e em decorrência disso "ele fabrica significados e produz símbolos - isso é o que o distingue do resto do mundo vivo". Este é o único trabalho que menciona na bibliografia Ketz De Vries reconhecido pesquisador em psicopatologia organizacional do INSEAD na França.

Iniciando a terceira parte que aborda as perspectivas brasileiras Mendes, Araújo e Merlo propõem um trabalho sobre Prática Clínica em psicodinâmica do trabalho: Experiências Brasileiras, fazendo comentários sobre a obra de Christophe Dejours e apresentam a experiência empírica de pesquisadores que contempla a pré-pesquisa, a pesquisa propriamente dita, análise da demanda e do material da pesquisa, observação clínica, interpretação, validação e refutação dos resultados. Finalmente identificam as diretrizes de apresentação e discussão com os participantes da pesquisa frente dos resultados por ela obtidos.
De maneira semelhante ao artigo anterior Silva, Barros e Lousada fazem um apanhado dos trabalhos e publicações Yves Clot. O artigo cobre os aspectos voltados a Clínica da atividade com um olhar histórico sobre a análise do trabalho. Abordam também o trabalhar e o "sair de si"como função psicológica do trabalho, as metodologias de análise do trabalho e, finalmente, os percursos da Clínica da Atividade no Brasil.

Carretero e Barros enfatizam no artigo onze as Clínicas do trabalho: contribuições da psicossociologia no Brasil divulgando nomes dos inúmeros profissionais que se dedicam ao assunto. O artigo é essencialmente teórico. Vale lembrar que as autoras, embora não se aprofundem, abordam o problema da terceirização como fonte de insegurança e impossibilidade de controle da própria vida.

O décimo segundo artigo é assinado por Lima que apresenta as Abordagens Clínicas e Saúde Mental no trabalho. Trata-se de um enfoque apenas teórico sobre a história cronológica dessas abordagens. A autora analisa essas abordagens no campo da clínica do trabalho na França dando grande ênfase à obra de Christophe Dejours.

O livro termina com um artigo de Athayde e Brito sobre o tema da Ergologia e Clínica de Trabalho indo além do biológico, psicológico, social e institucional. A ergologia busca compreender e intervir no conjunto dos problemas gerados pelo processo de produção. São mencionados acidentes e adoecimentos, dificuldade de comunicação e de desenvolvimento de competências, produtividade e qualidade aquém do esperado.

Provavelmente esta terceira parte poderia sofrer uma revisão dos seus autores para que seja feito um cotejamento entre os temas e não haja repetição de assuntos. 